Available online at: http://ejournal-balitbang.kkp.go.id/index.php/iaj

\title{
ANALYSIS OF GROWTH OF LALAWAK Barbonymus balleroides (VALENCIENNES, 1842) IN THREE CULTURE METHODS
}

\author{
Deni Radona\#, Vitas Atmadi Prakoso, and Irin Iriana Kusmini \\ Institute for Freshwater Aquaculture Research and Fisheries Extension \\ (Received April 2017; Final revised 19 June 2017; Accepted 19 June 2017)
}

\begin{abstract}
In fish culture, optimal growth could be influenced by various culture methods. Aim of the study was to evaluate the productivity of Barbonymus balleroides, lalawak in floating net cages, concrete ponds, and earthen ponds. Cultivation was designed with the circulation water system. Experiment was conducted using completely randomized design with three treatments and three replications for each treatment. The experimental fish, sized of $4.20 \pm 0.64 \mathrm{~cm} \mathrm{SL}$ and weight of $2.14 \pm 0.99 \mathrm{~g}$, were obtained from induced breeding. The stocking density used was 20 individuals $/ \mathrm{m}^{3}$. Fish were fed $3 \%$ of total weight two times every day using commercial pellet with $35 \%$ protein content for 90 day. The result showed that lalawak reared in earthen pond was no significant difference on length, weight, and biomass compared with that one in concrete pond $(P>0.05)$, but significantly different $(P<0.05)$ with floating net cages. There were no different $(P>0.05)$ among the three different culture systems for survival rate and FCR. Lalawak reared on earthen pond system supported with optimal water quality could increase productivity value.
\end{abstract}

\section{KEYWORDS: lalawak; growth; culture; ponds; floating net cages}

\section{INTRODUCTION}

Lalawak Barbonymus balleroides is a native fish from Indonesian waters. The fish is known as the commodities of high economic value for consumption. In West Java Province, lalawak spread widely in Sumedang and Cianjur Districts. In nature, this fish live at the bottom side of fast-flowing waters such as rivers and lakes. Lalawak is classified as herbivorous species which eat aquatic plants.

Domestication of lalawak in Indonesian has been conducted since 2006 but has not been carried out intensively (Yulfiperius, 2006). Domestication is only limited studies on morphological characteristics and reproductive aspects using nutrition and the environment approach. Aquaculture of lalawak was conducted since the population of lalawak as local species is become scare in the freshwaters due to the high catching levels of wild. According to Sukadi et al. (2011), aquaculture development based on local species of fish should be done in order to maintain of biodiversity and the development of aquaculture for food security. Since the lalawak population has be-

\footnotetext{
\# Correspondence: Institute for Freshwater Aquaculture Research and Fisheries Extension. JI. Sempur No.1, Bogor 16154, West Java, Indonesian.

Phone: + (0251) 8313200

E-mail: deniradona_kkp@yahoo.com
}

coming rare due to the high exploitation in the wild, the culture activity should be done to conserve it as the potential local species for sustainability and food security.

In order to support the domestication program, management system of aquaculture is required. The proper culture system is needed to support optimum fish growth. Kusmini et al. (2017) reported that lalawak reared in the aquarium for 90 days with a density of 4 individuals/L has a survival rate value of $54 \%$ and specific growth rate of $2 \%$ day. This study aimed to evaluate the productivity of lalawak in floating net cages, concrete pond, and earthen pond.

\section{MATERIALS AND METHODS}

This study was conducted in March-June 2016 in Germplasm Research Station, Cijeruk, Bogor. The lalawak fish, sized of $4.20 \pm 0.64 \mathrm{~cm} \mathrm{SL}$ and weight of $2.14 \pm 0.99 \mathrm{~g}$, used in this experiment were obtained from induced breeding. Induced breeding method was referred to tinfoil barb Barbonymus schwanenfeldii (Huwoyon \& Sukadi, 2009). Fish was reared in (A) floating net cages sized $2 \mathrm{~m} \times 2 \mathrm{~m} \times 2 \mathrm{~m}$; (B) concrete pond sized $5 \mathrm{~m} \times 2 \mathrm{~m} \times 1 \mathrm{~m}$; and (C) earthen pond system sized $8 \mathrm{~m} \times 5 \mathrm{~m} \times 1 \mathrm{~m}$. Stocking was density of 20 individuals $/ \mathrm{m}^{3}$. All rearing facilities were equipped with recirculating system. Completely 
randomized design (CRD) with three treatments and three replications for each treatment was applied. During 90 -day rearing activity, fish were fed $3 \%$ body weight twice every day with commercial pellet containing $35 \%$ of protein.

Fish growth, thirty fish for each group was measured for length and weight every 30 days. Parameters observed were absolute of length and weight gain, biomass, specific growth rate, survival rate, and feed conversion ratio (FCR).

Water quality was also observed during the study. Data were collected from inlet, outlet, and middle area of the waters of each culture system. Temperature parameters $\left({ }^{\circ} \mathrm{C}\right), \mathrm{pH}$, and dissolved oxygen $(\mathrm{mg} /$ $\mathrm{L})$ were measured by using Multi Parameter Water Quality M eter EC 900 with intervals of three hours within 24 hours. Hardness (mg/L CaCO3), nitrate (mg/L), nitrite (mg/L), TAN (Total ammonia nitrogen) (mg/L), and TOM (total organic matter) (mg/L) was observed in laboratory of Institute for Freshwater Aquaculture Research and Fisheries Extension, Bogor (ISO 17025:2008; Accreditation number: LP-711 IDN).

Collected data was tabulated and analyzed using analysis of variance (ANOVA) on 95\% confidence interval. Differences among treatments were analyzed further with Duncan test using SPSS version 18. Water quality parameters were analyzed qual itatively.

\section{RESULTS AND DISCUSSIONS}

\section{Growth Performance}

The results showed that lalawak grew faster in earthen pond than others. Significantly different $(P<0.05)$ with floating net cages. Weight, length, and specific growth rate of lalawak were shown in Table 1 and growth every 30 days were shown in Figure 1 and 2.

Lalawak reared on earthen pond culture system were shown best of growth performance with length value $(3.16 \mathrm{~cm})$, weight $(9.93 \mathrm{~g})$, and specific growth rate $(0.62 \%$ day) of length and $(1.91 \%$ day) of weight. Length and weight gain of lalawak in earthen pond increased $31 \%$ and $67 \%$ compared with in floating net cages. The earthen pond enabled to raise the growth of lalawak due to environmental conditions and the behavior of fish that lives on the bottom of the water was make it more likely to get natural feed. The value of water quality in earthen pond showed optimum temperature (T), dissolved oxygen (DO) and total organic matter (TOM) values $\left(\mathrm{T}: 24^{\circ} \mathrm{C}-28^{\circ} \mathrm{C}\right.$; DO: 3.31 $5.78 \mathrm{mg} / \mathrm{L}$; and TOM: $15.76-22.58 \mathrm{mg} / \mathrm{L})$ compared to floating net cages culture system $\left(\mathrm{T}: 22^{\circ} \mathrm{C}-26^{\circ} \mathrm{C}\right.$; DO: 3.21-4.21 mg/L; and TOM: $18.01-24.77 \mathrm{mg} / \mathrm{L}$ ), and concrete pond $\left(\mathrm{T}: 22^{\circ} \mathrm{C}-26.8^{\circ} \mathrm{C}\right.$; D0: $3.79-5.23 \mathrm{mg} / \mathrm{L}$; and TOM: $16.96-22.37 \mathrm{mg} / \mathrm{L})$. Thus the growth of the fish would be optimal. Temperature and oxygen levels would affect the metabolic processes of fish and will increase the fed activity there by accelerating of the growth (Besson et al., 2016; Emaliana et al., 2016; Sun $\&$ Chen, 2014; Wexler et al., 2011; Mallya, 2007). Low and overly higher temperature was also not good for fish growth. Kelabora (2010) declared that temperature and oxygen levels beyond optimal range could result in energy utilization mostly would spend for the adaptation to environments, which can disturb the metabolic system or the exchange substances. Meanwhile, Emaliana et al. (2016), stated that optimum temperature on goldfish growth ranges from $26^{\circ} \mathrm{C}-31^{\circ} \mathrm{C}$ and oxygen levels $>4 \mathrm{mg} / \mathrm{L}$. Moreover, Neilan \& Rose (2014) reported low levels of oxygen $(<2.5 \mathrm{mg} / \mathrm{L})$ would cause mortality increase $(>50 \%)$ in fish larvae and behavioral disturbance in juvenile of gulf killifish, whereas Tran-Ngoc et al. (2016) reported low levels of oxygen $(<3.5 \mathrm{mg} / \mathrm{L})$ in tilapia could reduce nutrient digestibility and intestinal morphology changes.

In order to maintain the optimum amount of oxygen levels in the water, the parameters to be considered is TOM. TOM is an indicator of dissolved oxygen consumption in water for oxidizing organic matter dissolved in water. The higher concentration of TOM, the higher concentration of organic matter (pollutants) would present in the water (Suryono \& Badjoeri, 2013).

\section{Survival Rate}

The observation of survival rate of lalawak for 90 days was shown in Figure 3. Survival rate value obtained was relatively high with highers survival value found at earthen pond culture system ( $98 \%$. Survival rate values obtained in three culture systems for 90 days showed no significant difference $(P>0.05)$.

Important factors that influence the survival rate of fish is water quality, especially temperature. Temperature can reduce dissolved oxygen levels in the waters if the range is not optimal. Temperature could influence the respiratory of fish (Emaliana et al., 2016). Meanwhile, according to Murjani (2011), the survival of fish was depending on fish adaptation to environment and water quality. In this study, no significant differences found on survival rate in each culture systems, which means that lalawak could tolerate environmental waters in each culture systems. 
Table 1. Weight gain, length gain, and specific growth rate of lalawak in different aquaculture system

\begin{tabular}{lccc}
\hline \multirow{2}{*}{ Growth parameters } & \multicolumn{3}{c}{ Aquaculture system } \\
\cline { 2 - 4 } & Floating net cages & Concrete pond & Earthen pond \\
\hline Initial length (cm) & $4.20 \pm 0.64$ & $4.20 \pm 0.64$ & $4.20 \pm 0.64$ \\
Initial body weight (g) & $2.14 \pm 0.99$ & $2.14 \pm 0.99$ & $2.14 \pm 0.99$ \\
Final length (cm) & $6.60 \pm 0.09$ & $7.08 \pm 0.12$ & $7.36 \pm 0.39$ \\
Final body weight (g) & $8.07 \pm 0.65$ & $9.84 \pm 0.49$ & $12.06 \pm 2.01$ \\
Absolute length (cm) & $2.40 \pm 0.11^{\mathrm{a}}$ & $2.88 \pm 0.15^{\mathrm{ab}}$ & $3.16 \pm 0.47^{\mathrm{b}}$ \\
Absolute weight (g) & $5.93 \pm 0.79^{\mathrm{a}}$ & $7.70 \pm 0.60^{\mathrm{ab}}$ & $9.93 \pm 2.46^{\mathrm{b}}$ \\
Specific growth rate of length (\%/day) & $0.50 \pm 0.02^{\mathrm{a}}$ & $0.58 \pm 0.02^{\mathrm{ab}}$ & $0.62 \pm 0.07^{\mathrm{b}}$ \\
Specific growth rate of weight (\%dday) & $1.47 \pm 0.11^{\mathrm{a}}$ & $1.69 \pm 0.07^{\mathrm{ab}}$ & $1.91 \pm 0.22^{\mathrm{b}}$ \\
\hline
\end{tabular}

Remarks: Numbers followed by the same superscript letter in the same line indicates no significantly difference $(P>0.05)$

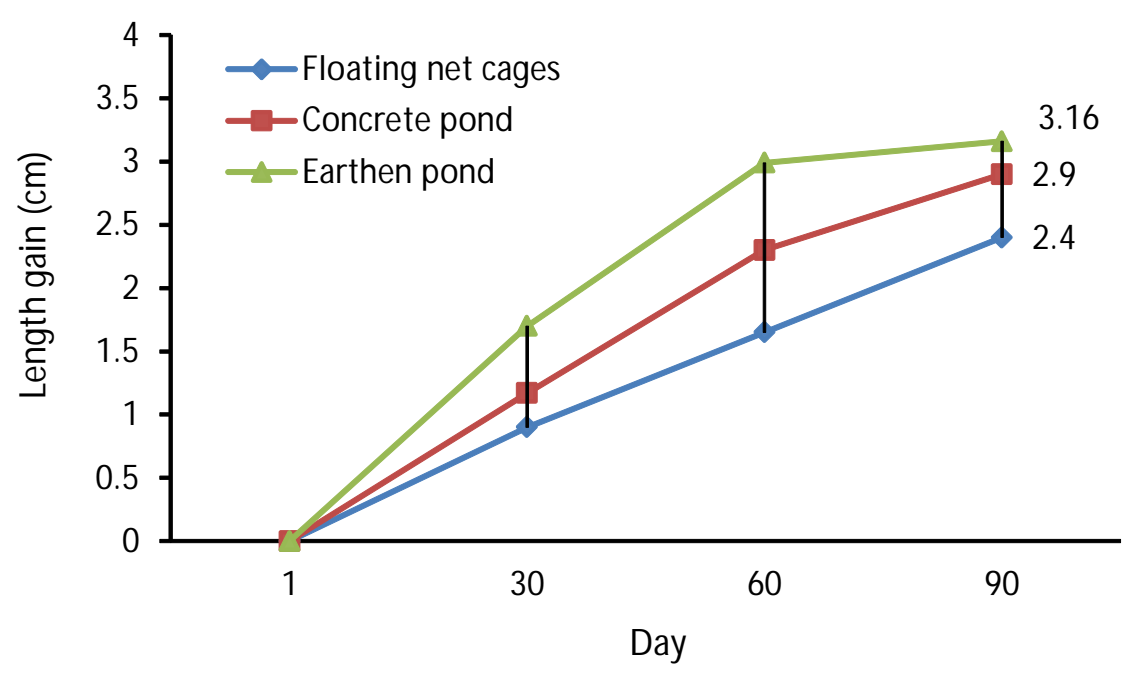

Figure 1. Length gain on seedling of lalawak for 90 days.

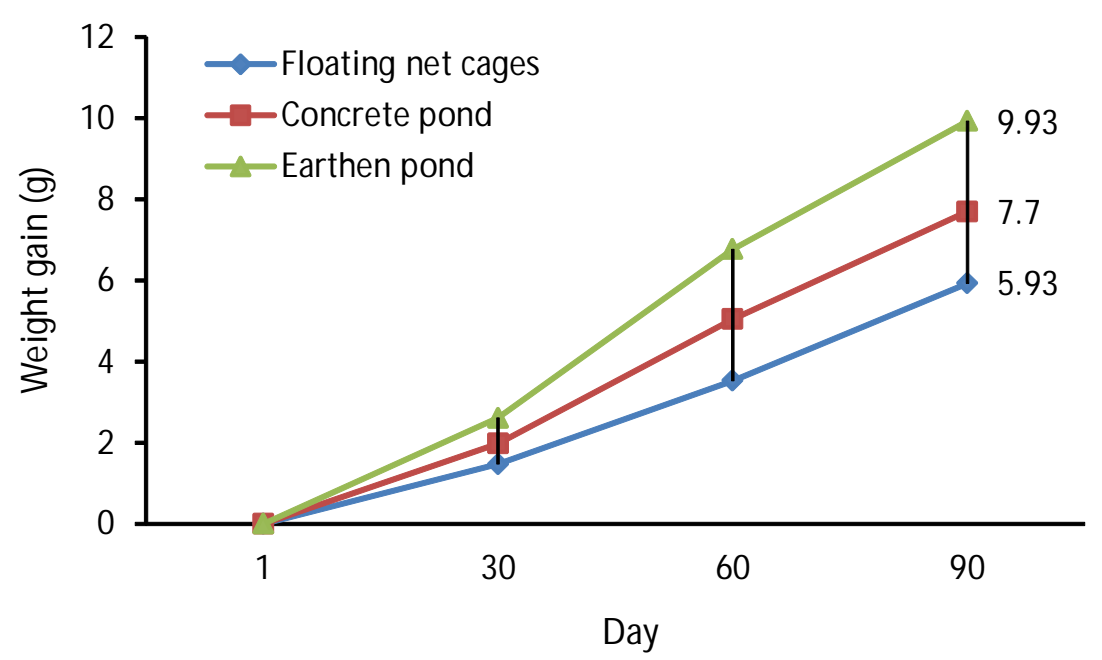

Figure 2. Weight gain on seedling of lalawak for 90 days. 


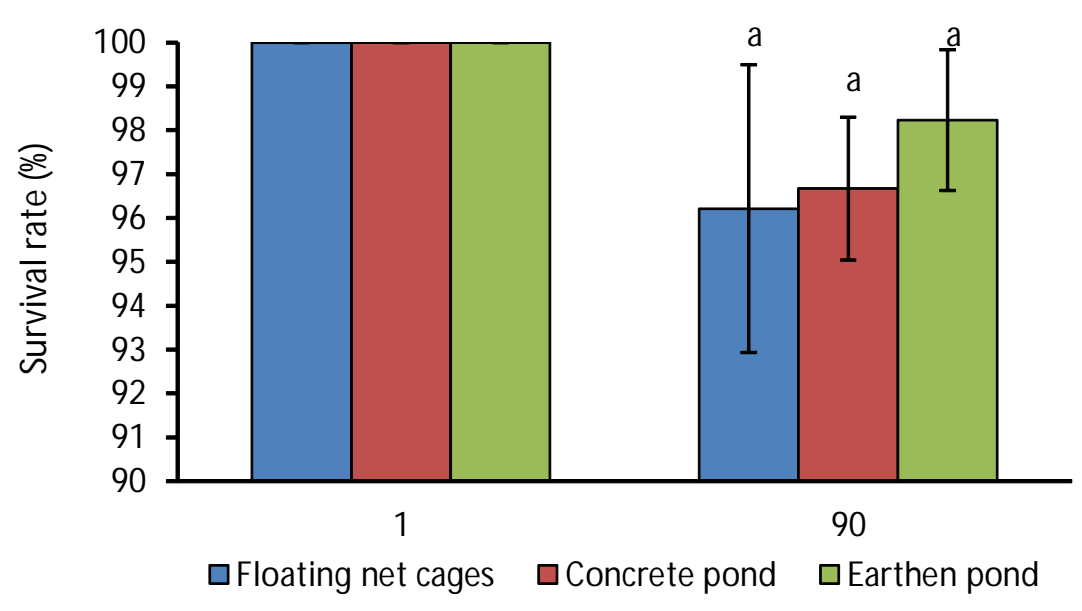

Day

Figure 3. Survival rate of lalawak for 90 days.

\section{Biomass and Feed Conversion Ratio (FCR)}

The observation biomass and feed conversion ratio (FCR) of lalawak for 90 days experiment were presented in Table 2. The result of research of multisystem aquaculture of lalawak showed significant differences on biomass $(P<0.05)$. Lalawak reared in the earthen pond culture system has a higher biomass values $(1,461.05 \pm 37.41 \mathrm{~g})$ compared with concrete pond culture systems $(1,437.50 \pm 18.86 \mathrm{~g})$ and floating net cages $(1,180.85 \pm 24.21 \mathrm{~g})$. This results indicates that lalawak on earthen pond culture system has more capabality of utilize the feed. Mulyadi et al. (2010) stated that the value of biomass is strongly influenced to the efficiency in feed utilization.

FCR values obtained in the three culture systems were statistically not significantly different $(P>0.05)$. FCR value showed the utilization of nutrients feed by the fish. Based on observation of lalawak reared in the three culture systems showed that fish could utilize the feed efficiently.

\section{Water Quality}

The results of water quality measurement during the experiment was showed at Table 3. Water quality is one of the supporting factors that could support the growth and survival rate of in the fish. In general, water quality values was obtained from the three culture systems showed the limits of tolerance value for the growth and survival of fish (Boyd, 1982; Zooneveld et al., 1991). Meanwhile according Yulfiperius (2006) and Kotellat (1993), lalawak could live optimally at temperature $25^{\circ} \mathrm{C}-28^{\circ} \mathrm{C}, \mathrm{pH} 6-7$, and dissolved oxygen 3.43-6.61 mg/L. Based on water quality data obtained in the three culture systems, it showed that water quality on earthen pond culture system showed optimal value with a temperature of $24^{\circ} \mathrm{C}-28.4^{\circ} \mathrm{C}$ and dissolved oxygen of $3.31-5.78 \mathrm{mg} / \mathrm{L}$.

Table 2. Biomass value and FCR on seedling of lalawak

\begin{tabular}{lccc}
\hline \multirow{2}{*}{ Parameters } & \multicolumn{3}{c}{ Aquaculture system } \\
\cline { 2 - 4 } & Floating net cages & Concrete pond & Earthen pond \\
\hline Initial biomass $(\mathrm{g})$ & $321.5 \pm 2.05$ & $321.5 \pm 2.05$ & $321.5 \pm 2.05$ \\
Final biomass $(\mathrm{g})$ & $1180.85 \pm 24.21$ & $1437.50 \pm 18.86$ & $1782.55 \pm 37.41$ \\
Absolute biomass $(\mathrm{g})$ & $859.35 \pm 24.21^{\mathrm{a}}$ & $1116.00 \pm 18.86^{\mathrm{b}}$ & $1461.05 \pm 37.41^{\mathrm{c}}$ \\
FCR & $1.31 \pm 0.51^{\mathrm{a}}$ & $1.37 \pm 0.38^{\mathrm{a}}$ & $1.13 \pm 0.11^{\mathrm{a}}$ \\
\hline
\end{tabular}

Remarks: Numbers followed by the same superscript letter in the same line indicates no significantly difference $(P>0.05)$ 
Table 3. The value of water quality in the pond during the experiment

\begin{tabular}{|c|c|c|c|c|}
\hline \multirow{2}{*}{ Variable (Water quality) } & \multicolumn{3}{|c|}{ Range } & \multirow{2}{*}{ Analysis technique } \\
\hline & Floating net cages & Concrete pond & Earthen pond & \\
\hline Temperature $\left({ }^{\circ} \mathrm{C}\right)$ & $22-26$ & $22-26.8$ & $24-28.4$ & - \\
\hline $\mathrm{pH}$ & $6-7$ & $6-7$ & $6-7$ & - \\
\hline Dissolved oxygen (mg/L) & $3.21-4.21$ & $3.79-5.23$ & $3.31-5.78$ & - \\
\hline Hardness (mg/L) & $73.15-94.05$ & $73.15-94.05$ & $78.37-104.50$ & SNI 06-6989.12-004 \\
\hline Nitrate (mg/L) & $0.37-0.73$ & $0.36-0.56$ & $0.38-0.86$ & - \\
\hline Nitrite (mg/L) & $0.17-0.20$ & $0.14-0.18$ & $0.18-0.20$ & SNI 06-6989.29-004 \\
\hline Total ammonium nitrogen (mg/L) & $0.12-0.33$ & $0.15-0.48$ & $0.25-0.91$ & SNI 06-6989.30-004 \\
\hline Total organic matter (mg/L) & $18.01-24.77$ & $16.96-22.37$ & $15.76-22.58$ & SNI 06-6989.22-004 \\
\hline
\end{tabular}

\section{CONCLUSION}

The culture systems could determine the productivity of lalawak in which reared in earthen pond culture system provided optimum of length and weight gain.

\section{ACKNOWLEDGEMENT}

We thank to Institute for Freshwater Aquaculture Research and Fisheries Extension for funded this research. We also Thank to Mr. Sudarmaji, Heppy Aprilistianto, and Miss Fera Permata Putri for their assistance provided during the experiment.

\section{REFERENCES}

Besson, M., Vandeputte, M., Arendonk, J.A.M., Aubin, J., De Boer, I.J.M., Quillet, E., \& Komen, H. (2016). Influence of water temperature on the economic value of growth rate in fish farming: The case of sea bass Dicentrarchus labrax cage farming in the Mediterranean. Aquaculture, 2016: Accepted manuscript.

Boyd, C.E. (1982). Water quality management in fish pond culture. International Centre for Aquaculture Experiment Station. Alabama: Auburn University Press, 359 pp.

Emaliana, Usman, S., \& Lesmana, I. (2016). The influence of the temperature againts the growth of the seed goldfish koi Cyprinus carpio. Jurnal Aquacoastmarine, 13 (3): 2-10 (in Indonesian with English abstract).

Huwoyon, G.H. \& Sukadi, M.F. (2009). Egg-hatching of tinfoil barb Barbonymus schwanenfeldii potential local species for stock enhancement in West Kalimantan. Proceeding of the National Forum of fish Resources Enrichment, 2nd. p. 1-9.

Kelabora, D.M. (2010). The influence of temperature on the survival and growth of larval carp Cyprinus carpio. Terubuk, 38(1), 71-81 (in Indonesian with English abstract).
Kotellat, M., Whitten, A.J., Kartikasari, S.N., \& Wirjoatmodjo, S. (1993). Freshwater fishes of western Indonesia and Sulawesi (Hardbound). Jakarta: Periplus, 344 pp.

Kusmini, I.I., Putri, F.P., \& Radona, D. (2017). The growth and survival rate of red tailed tinfoil, Barbonymus balleroides Valenciennes, 1842 postlarvae in aquariums with different densities. Jurnal Iktiologi Indonesia, 17(1), 21-27 (in Indonesian with English abstract).

Mallya, Y.J. (2007). The effects of dissolved oxygen on fish growth in aquaculture. UNU-Fisheries Training Programme, $30 \mathrm{pp}$.

Mulyadi, Usman, M.T., \& Suryani. (2010). The influence of different feeding frequency on the growth and survival of silais seed Ompok hypophthalmus. Terubuk, 38(2), 21-40 (In Indonesian).

Murjani, A. (2011). Culture some variety of fish Sepat Swamp Trichogaster trichopterus with the feeding commercial fed. Jurnal Fish Scientiae, 1(2), 214-233 (In Indonesian).

Neilan, R.M. \& Rose, K. (2014). Simulating the effect of fluctuating dissolved oxygen on growth, reproduction, and survival of fish and shrimp. Journal of Theoretical Biology, 343, 54-68.

Sun, L. \& Chen, H. (2014). Effects of water temperature and fish size on growth and bioenergetics of cobia Rachycentron canadum. Aquaculture, 426-427, 172-180.

Sukadi, M.F., Widiyati, A., Nugroho, E., Komarudin, O., Azwar, Z.I., Prihadi, T.H., \& Huwoyon, G.H. (2011). Analysis of locally fish commodities in Central Kalimantan in aquaculture development policy analysis 2011. Agency for Marine and Fisheries Research and Development. Center for Aquaculture Research and Development, p. 213231 (In Indonesian).

Suryono, T. \& Badjoeri, M. (2013). Water quality tests on enlargement larva eels Anguilla sp. maintenance 
system with two difference. Limnotek, 20(2), 169177 (in Indonesian with English abstract).

Tran-Ngoc, K.T., Dinh, N.T., Nguyen, T.H., Roem, A.J., Schrama, J.W., \& Verreth, J.A.J. (2016). Interaction between dissolved oxygen concentration and diet composition on growth, digestibility and intestinal health of Nile tilapia Oreochromis niloticus. Aquaculture, 2016: Accepted manuscript.

Wexler, J., Margulies, D., \& Scholey, V. (2011). Temperature and dissolved oxygen requirements for survival of yellowfin tuna Thunnus albacares, larvae. Journal of Experimental Marine Biology and Ecology, 404, 63-72.

Yulfiperius. (2006). Domestication and breeding of the lalawak Barbonymus balleroides in effort for its conservation. Dissertation. Bogor Agricultural University. Bogor, 156 pp (in Indonesian with English abstract).

Zonneveld, N., Huisman, E.A., \& Boon, J.H. (1991). Principles for breeding of fish. Jakarta: Gramedia Pustaka Utama, 317 pp. 